\title{
TIPOLOGI PANTAI UNTUK OLAHRAGA SURFING DI PULAU KARAM KECAMATAN KOTO XI TARUSAN KABUPATEN PESISIR SELATAN
}

\author{
Ardian Syahroni ${ }^{1}$, Helfia Edial ${ }^{2}$, Widya Prarikeslan ${ }^{2}$ \\ Program Studi Geografi, \\ Fakultas Ilmu Sosial, Universitas Negeri Padang
}

\begin{abstract}
Abstrak
Penelitian ini bertujuan untuk: 1) mengetahui tipologi pantai pada daerah Pulau Karam Kecamatan Koto XI Tarusan Pesisir Selatan. 2) mengetahui karakteristik gelombang (panjang, indek hempasan) yang ada di Pulau Karam Kecamatan Koto XI Tarusan Pesisir Selatan. 3) mengetahui tipe gelombang untuk kesesuaian surfing di Pulau Karam Kecamatan Koto XI Tarusan Pesisir Selatan.Penelitian ini digolongkan ke dalam penelitian deskriptif, dengan metode Survey. Satuan pemetaan adalah batasan garis pantai/Shore line dengan pengambilan sampel penelitian digunakan sampel area, dan teknik pengambilannya bersifat purposive sampling. Hasil dari penelitian ini adalah: 1) tipologi pantai adalah bura (pesisir endapan sungai) dan pesisir bergisik beting (pesisir endapan marin). 2) nilai rata-rata panjang gelombang (Lo) adalah 177,58 meter, nilai ratarata tinggi hempasan gelombang (Hb adalah sekitar 1,73.meter. 3) tipe gelombang adalah Plunging, Spiling, dan Surging. Tipologi dan tipe gelombang yang cocok pada pantai pulau karam terdapat pada sampel I dan berdasarkan ketinggian gelombang untuk kriteria surfer adalah pemula/amatir.
\end{abstract}

Kata Kunci :Tipologi Pantai, Tipe Gelombang.

\begin{abstract}
This study is purposed to: 1) find out shore typology in Karam Island Koto XI Tarusan district Pesisir Selatan regency, 2) to find out wave characteristics (length \& slam index), 3) to find out wave types for surfing activity in Karam Island Koto XI Tarusan district Pesisir Selatan regency.

This study was classified into descriptive study with survey method. Data in this study was primary data that came from field observation and secondary data which was collected from related agencies. Mapping unit that used in this study was shore line with study object was shore in Karam Island Koto XI Tarusan district Pesisir Selatan regency. Sample was obtained by purposive sampling technique. Study findings are: 1) shore topology is bura (alluvial coast) and marine coast, 2) average wave length (LO) and average slam height $(\mathrm{Hb})$ are $177.58 \mathrm{~m}$ and $1.73 \mathrm{~m}$, respectively, 3) wave types are plunging, spilling, and surging. Shore typology and wave type based on wave height and wave period in area of sample I in Karam Island Koto XI Tarusan district Pesisir Selatan regency is suitable for amateur surfer.
\end{abstract}

Key Words: Shore Typology, Wave type

\footnotetext{
${ }^{1}$ Mahasiswa Program Studi Geografi untuk Wisuda September 2017

${ }^{2}$ Dosen Jurusan Geografi Fakultas Ilmu Sosial Universitas Negeri Padang
} 


\section{PENDAHULUAN}

Provinsi Sumatera Barat merupakan salah satu tujuan bagi surfer, karena tipologi pantai sesuai dan salah satu spot yang sesuai dan terbaik di dunia yang terletak di kabupaten mentawai. Mentawai surga bagi para peselancar atau surfer. Selain traveler dari tiap daerah di Indonesia, turis mancanegara juga datang ke sini dan ingin merasakan sensasinya, tak heran gelombang di Mentawai disebut sebagai salah satu yang terbaik di dunia. Ada dua spot di Mentawai, spot Lances Right dan Macaronies masuk ke dalam 10 spot terbaik dunia. Ketinggian ombak di pulau Mentawai mencapai tujuh meter dan di Sumatera Barat juga sudah ada club atau anggota surfer di bentuk tepatnya di Kota Pariaman dan nama kelompok tersebut Pariaman Surfer Family, suatu kelompok anak muda yang bergerak dicabang olahraga surfing. Pariaman Surfer Family terbentuk pada tahun 2003, pada waktu itu hanya mempuyai sepuluh orang anggota, jadi Pariaman Surfer Family belum siap untuk membentuk surfer.

Kabupaten Pesisir Selatan memiliki luas wilayah 5.749,89 $\mathrm{km}^{2}$ dan populasinya \pm 420.000 jiwa. Kabupaten Pesisir Selatan terletak di pinggir pantai, dengan garis pantai sepanjang $218 \mathrm{~km}$ dan topografinya terdiri dari daratan, gunung dan perbukitan yang merupakan perpanjangan perpanjangan gugusan Bukit Barisan. Berdasarkan penggunaan lahan, 45,29\% wilayah terdiri dari hutan, termasuk kawasan Taman Nasional Kerinci Seblat, Cagar Alam Koto XI Tarusan,dan rawa gambut.

Pesisir Selatan terdapat sebuah objek wisata pantai yang sangat indah yaitu objek wisata pantai Carocok.
Tipologi pantai ini memiliki pasir putih serta air jernih, memiliki tepi pantai yang landai, sehingga bisa berenang bagi anak-anak dan orang dewasa. Panjang garis pantai tersebut tentu memiliki berbagai sumber daya yang dapat dimanfaatkan untuk melakukan berbagai jenis olahraga air, seperti jet ski, donat boat, banana boat, perahu karet dan surfing. Koto XI Tarusan adalah sebuah kecamatan yang terletak di utara Kabupaten Pesisir Selatan yang berbatasan dengan Kota Padang sebelah selatan berbatasan dengan Kecamatan Bayang.

Surfing merupakan seni olahraga menikmati alam, dimana di dalamnya ada unsur penaklukan, sama seperti olahraga lainnya, disini ada trend dan mode. Surfing adalah gaya hidup seperti juga gaya hidup anak punk yang bukan sekedar musik, surfing mempunyai media sendiri, mode, trend, dan tempat berkumpul. Menurut Harry, pengamat dan peselancar yang tinggal di Bali, hanya di Bali dan Jakarta yang menyediakan beragam keperluan surfing dan di Bali sudah meledak, indikasinya ada puluhan toko surfing, dimana beberapa perusahaan surfing local, mendapat lisensi dari peusahaan luar negeri, sehingga bisa memproduksi piranti surfing sendiri. (http//www.Baliexe.com/SurfInfo),

Daerah kawasan Pulau Karam Kecamatan Koto XI Tarusan Kabupaten Pesisir Selatan memiliki pantai yang indah tetapi masih banyak wisatawan yang tidak mengetahui pantai tersebut, jadi untuk meningkatkan daya tarik wisatawan ke Pantai Pulau Karam Kecamatan Koto XI Tarusan Kabupaten Pesisir Selatan maka di adakan sebuah atraksi seperti olahraga surfing di karenakan di daerah Pulau Karam Kecamatan Koto 
XI Tarusan Kabupaten Pesisir Selatan tipe gelombangnya cukup memungkinkan untuk olahraga surfing.

Berdasarkan latar belakang yang telah diuraikan di atas tentang olahraga surfing maka, penulis ingin melakukan suatu penelitian tentang daerah mana yang sesuai untuk melakukan kegiatan olahraga surfing tersebut dan penelitian ini diberi judul "Tipologi Pantai Untuk Olahraga Surfing di Pulau Karam Kecamatan Koto XI Tarusan Kabupaten Pesisir Selatan"

\section{METODE PENELITIAN}

Setelah tipologi pantai, nilai tinggi gelombang, periode gelombang, sudut kemiringan dasar tepi pantai dapatkan, maka data tersebut diolah dengan rumus analisa data, sehingga parameter geloambang yang kita cari sesuai dengan tujuan penelitian ini diketahui nilainya. Analsisi data yang. dilakukan dalam penelitian ini adalah a. sebagai berikut:

\section{Analisis Tipologi Pantai}

Analisis tipologi didasarkan pada hasil interpretasi dan analisis terhadap berbagai sumber data yang tersedia, yaitu: peta geologi \$kala 1:50000 dari Pusat Penelitian dan Geologi, Direktorat Sumberdaya Mineral Bandung tahun 1990. Peta geologi ini digunakan sebagai dasar untuk analisis aspek fisik utamanya untuk menentukan klasifikasi materi penyusun kawasan pesisir.

Selanjutnya untuk aspek biotik (hayati) disusun berasaskan peta vegetasi dengan nomenklatur seper $\dot{2}$. tercantum pada hasil dari interpreta: data tersebut juga divalida: berasaskan data yang tersedia seper citra pengindraan jauh utamanya data LANDSAT OLI 8 yang tercakup dalam Program Marine Resource
Evaluation and Planning (MREP) (Suprajaka, 2005). Kemudian mengacu pada table 2 klasifikasi tipologi pantai di bawah ini hal 26. Untuk lebih jelas kita dapat melihat tabel 1.

\section{Tipologi Pantai}

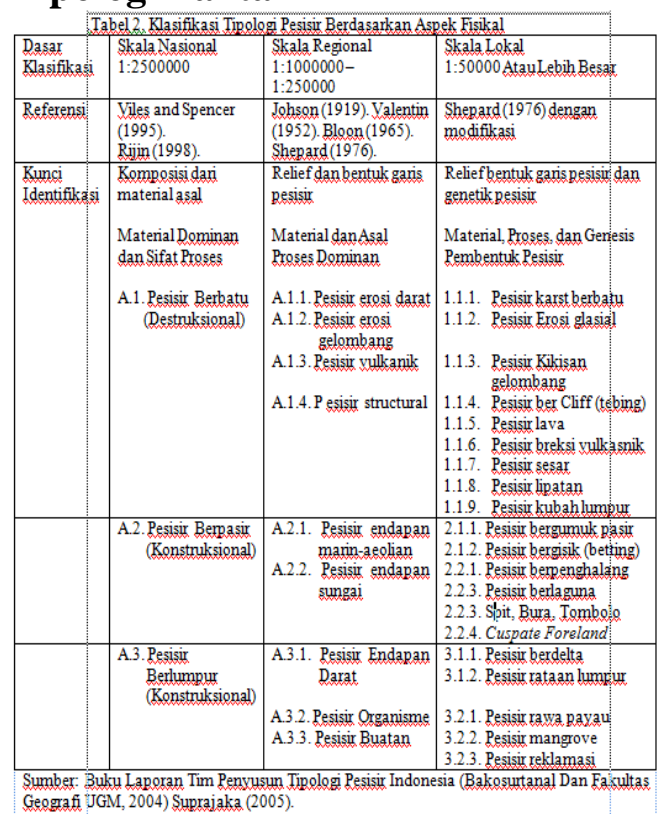

Analisis Karakteristik Gelombang

Panjang Gelombang

$$
\mathrm{L}_{0}=1,56 \mathrm{~T}^{2}
$$

$\mathrm{L}_{0} \quad=$ Panjang gelombang (meter)

$\mathrm{T}=$ Periode gelombang (detik)

(Pethichk 1984)

Indeks hempasan gelombang di daerah penelitian digunakan formula sebagai berikut : $K=\frac{\tan \alpha}{\sqrt{\frac{H_{0}}{L_{0}}}}$ Keterangan:

$\mathrm{K}=$ Indeks hempasan gelombang

$\tan \alpha=$ Sudut lereng gisik

Ho = Tinggi gelombang (Meter)

Lo = Panjang gelombang

Mengetahui tipe gelombang untuk kesesuaian surfing di Pulau Karam Kecamatan Koto XI Tarusan Pesisir Selatan

Dalam menentukan kesesuaian tipe Gelombang untuk olahraga surfing digunakan nilai indeks 
hempasan gelombang pada tabel \begin{tabular}{l} 
dibawah Sebagai \\
\begin{tabular}{|c|c|c|c|}
\hline Tabel 3. Kriteria Gelombang Yang Sesuai Untuk Surfing \\
\hline 1 & Tipe gelombang & $\begin{array}{c}\text { Nilai Indeks Hempasan } \\
\text { Gelombang }\end{array}$ & Kriteria \\
\hline 2 & Spilling & $<0,5$ & Cocok \\
\hline 3 & Sunging & $0,5-3,5$ & Sangat Cocok \\
\hline
\end{tabular} \\
\hline
\end{tabular}

\section{HASIL DAN PEMBAHASAN}

Dengan adanya hasil pengukuran di lapangan, maka di dapatkan nilai periode gelombang, tinggi gelombang, sudut lereng pantai pada daerah penelitian seperti Tabel di bawah ini:

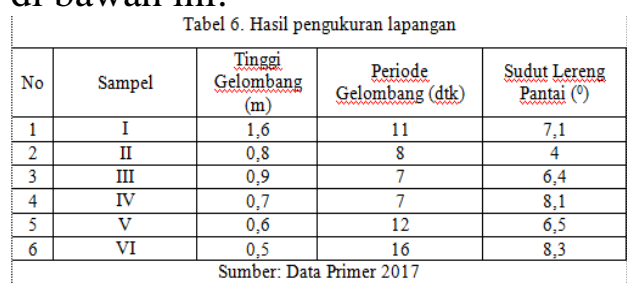

Berdasarkan Tabel di atas
dapat diketahui bahwa nilai gelombang tertinggi terdapat pada sampel I yaitu setinggi 1,6 meter dan gelombang terendah terdapat pada sampel V dan VI yaitu 0.6-0,5 meter. Rata-rata nilai tinggi gelombang pada daerah penelitian adalah 0.85 meter. Untuk lebih jelasnya data pengukuran tinggi gelombang dapat dilihat pada Gambar 2 hal 38.

Periode gelombang paling lama terjadi pada sampel VI yaitu 16 detik dan yang terendah terdapat pada sampel III dan IV yaitu 7 detik. Ratarata nilai periode gelombang pada daerah penelitian adalah 10,1 detik, unruk lebih jelas kita dapat melihat pada gambar hal 42.

Sudut lereng pantai tertinggi terdapat pada sampel VI yaitu $8,3^{\circ}$ dan yang terendah terdapat pada sampel II yaitu $4^{0}$. Rata-rata sudut lereng pantai pada daerah penelitian adalah $6,73^{\circ}$.

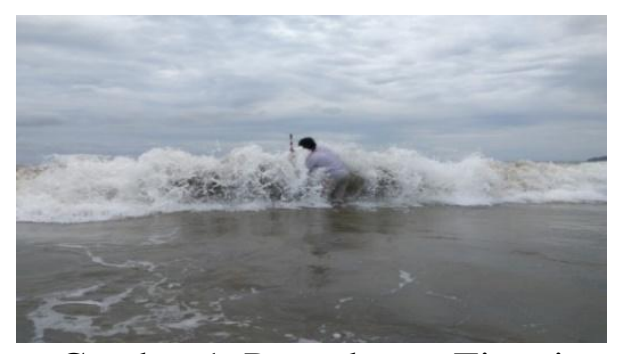

Gambar 1. Pengukuran Tinggi

Gelombang

(Sumber : Dokumentasi Penelitian 2017)

Periode gelombang hasil dari pengukuran lapangan yang terlama terdapat pada sampel VI dan yang paling sedikit terdapat pada sampel III dan sampel IV pada pulau karam kecamatan koto XI tarusan kabupaten pesisir selatan. Periode gelombang dihitung mulai dari membentuknya gelombang sampai pecahnya gelombang. Untuk lebih jelasnya data pengukuran tinggi gelombang dapat dilihat pada Gambar 13 dibawah ini:

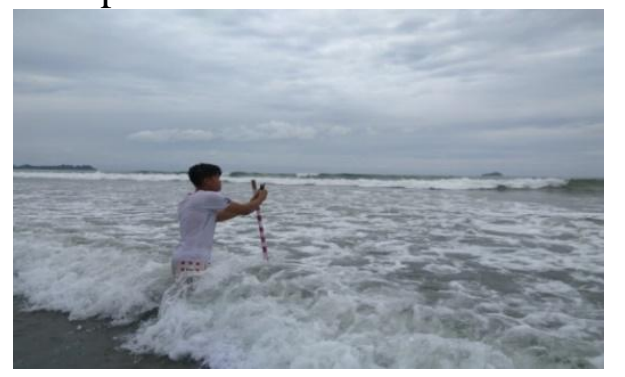

Gambar 2 : Menghitung Periode

Gelombang

(Sumber : Dokumentasi Penelitian 2017)

Sudut lereng pantai di Pulau Karam Kecamatan Koto XI Tarusan kabupaten Pesisir Selatan yang terlama terdapat pada sampel VI dan yang sedikit terdapat pada sampel II.

Setelah dianalisis data yang diperoleh di lapangan maka didapat tipologi, nilai panjang gelombang dan nilai indeks hempasan gelombang yang dapat dilihat pada tabel berikut ini: 
Untuk melihat tipologi pantai pada titik sampel kita dapat melihat pada tabel dibawah ini:

\begin{tabular}{|c|c|c|c|}
\hline No & Sampel & Tipologi Pantai & Genesis \\
\hline 1 & I & Bura & $\begin{array}{c}\text { Pesisir endapan } \\
\text { sungai }\end{array}$ \\
\hline 2 & II & Bura & $\begin{array}{c}\text { Pesisir endapan } \\
\text { sungai }\end{array}$ \\
\hline 3 & III & Bura & $\begin{array}{c}\text { Pesisir endapan } \\
\text { sungai }\end{array}$ \\
\hline 4 & IV & Bura & $\begin{array}{c}\text { Pesisir endapan } \\
\text { sungai }\end{array}$ \\
\hline 5 & V & Bura & $\begin{array}{c}\text { Pesisir endapan } \\
\text { sungai }\end{array}$ \\
\hline 6 & VI & Bura & $\begin{array}{c}\text { Pesisir endapan } \\
\text { sungai }\end{array}$ \\
\hline
\end{tabular}

Berdasarkan Tabel 7 hal 47 dapat di jelaskan bahwa tipologi pantai pada sampel I adalah Bura dan genesis batuannya pesisir endapan sungai, Pada sampel II-VI terdapat tipologi yang sama yaitu pesisir bergisik beting dan genesisnya pesisir endapan marin yang terdapat pantai 2 ) pulau karam kecamatan koto XI tarusan pesisir selatan.

Jika dilihat dari metode jenis pantainya adalah pantai berpasir dan sangat cocok untuk surfing di daerah pantai Pulau Karam Kecamatan Koto XI Tarusan Kabupaten Pesisir Selatan pada sampel I, Karena di pantai berbatu dan berlumpur tidak memungkinkan untuk melakukan olahraga surfing karena dinilai cukup berbahaya bagi seorang surfer.

a. Karakteristik gelombang untuk menentukan karakteristik gelombang pertama-tama harus mencari :

\section{1) Panjang Gelombang}

Untuk melihat panjang gelombang pada titik sampel kita. dapat melihat pada tabel dibawah ini: Tabel 8. Nilai Parameter Panjang Gelombang

\begin{tabular}{|c|c|c|}
\hline No & Sampel & $\begin{array}{l}\text { Panjang Gelombang } \\
\mathrm{L}_{0}=1,56 \mathrm{~T}^{2}(\mathrm{~m})\end{array}$ \\
\hline 1 & I & 188,76 \\
\hline 2 & II & 99,84 \\
\hline 3 & III & 76,44 \\
\hline 4 & IV & 76,44 \\
\hline 5 & V & 224,64 \\
\hline 6 & VI & 399,36 \\
\hline \multicolumn{3}{|c|}{ Sumber : Data primer 2017}
\end{tabular}

Berdasarkan rumus dan nilai panjang gelombang (Lo) pada Tabel 8 di atas, maka didapatkan bahwa nilai panjang gelombang ditentukan oleh periode gelombang. Semakin besar nilai periode gelombang maka makin besar pula nilai panjang gelombang.

Nilai panjang gelombang yang terpanjang pada daerah penelitian terdapat pada sampel VI yaitu 399,36 meter, sedangkan nilai panjang gelombang terpendek terdapat pada sampel III dan IV yaitu 76,44 meter. Rata-rata nilai panjang gelombang pada daerah penelitian adalah 177,58 meter.

\section{Indeks Hempasan Gelombang}

Untuk melihat indeks hempasan gelombang pada titik sampel kita dapat melihat pada tabel dibawah ini:

\begin{tabular}{|c|c|c|}
\hline No & Sampel & $\begin{array}{l}\text { Indeks Hempasan Gelombang } \\
\qquad K=\frac{\tan \alpha}{\sqrt{\frac{H_{0}}{L_{0}}}}\end{array}$ \\
\hline 1 & I & 1,3 \\
\hline 2 & II & 0,6 \\
\hline 3 & III & 0,1 \\
\hline 4 & IV & 1,4 \\
\hline 5 & V & 2,5 \\
\hline 6 & VI & 4,5 \\
\hline
\end{tabular}

Berdasarkan Tabel diatas dapat di jelaskan bahwa indeks hempasan gelombang tertinggi terdapat pada sampel VI dan yang terendah terdapat pada sampel III dan Rata-rata nilai indeks hempasan gelombang adalah 1,73 .

\section{Kesesuaian Tipe Gelombang Untuk Olahraga Surfing}

Untuk melihat tipe gelombang pada titik sampel kita dapat melihat pada tabel dibawah ini:

\begin{tabular}{|c|c|c|}
\hline \multirow{2}{*}{ No } & Sampe1 & $\begin{array}{c}\text { Tipe Gelombang } \\
\text { Pecah }\end{array}$ \\
\hline 1 & I & Plunging \\
\hline 2 & II & Spiling \\
\hline 3 & III & Spiling \\
\hline 4 & IV & Plunging \\
\hline 5 & V & Plunging \\
\hline 6 & VI & Surging \\
\hline \multicolumn{3}{|c|}{ Sumber : Data primer 2017 }
\end{tabular}


Berdasarkan Tabel diatas dapat di jelaskan bahwa pada tiap sampel terdapat perbedaan tipe gelombang, pada sampel I,IV,V terdapat tipe gelombang plunging, pada sampel II, III, terdapat tipe gelombang spiling dan tipe gelombang surging terdapat pada sampel VI.

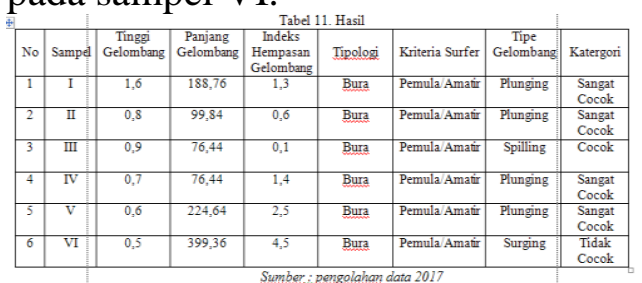

Berdasarkan Tabel diatas dapat di jelaskan bahwa :

1) Berdasarkan hasil perhitungan data dapat diketahui bahwa tipologinya bura dan tipe gelombang pada sampel I tersebut ialah plunging yang berarti bahwa tipe gelombang ini sangat cocok untuk melakukan olagraga surfing, tinggi gelombang di pantai ini 1,6 $\mathrm{m}$ dan periode gelombang 11 detik kriteria amatir/pemula, maka pada sampel I telah memenuhi semua syarat untuk melakukan olahraga surfing.

2) Berdasarkan hasil perhitungan data dapat diketahui bahwa tipologinya bura dan tipe gelombang pada sampel II tersebut ialah plunging yang berarti bahwa tipe gelombang ini sangat cocok untuk melakukan olagraga surfing, tinggi gelombang $0,8 \mathrm{~m}$ dan periode gelombang 8 detik kriteria amatir/pemula, maka pada sampel II tidak memenuhi semua syarat untuk bisa melakukan olahraga surfing karena tinggi gelombang di pantai ini hanya $0.8 \mathrm{~m}$.

3) Berdasarkan hasil perhitungan data dapat diketahui bahwa tipologinya bura tipe gelombang pada sampel III tersebut ialah spiling yang berarti bahwa tipe gelombang ini cocok untuk melakukan olagraga surfing, tinggi gelombang $0,9 \mathrm{~m}$ dan periode gelombang 7 detik kriteria amatir/pemula, maka pada sampel III tidak memenuhi semua syarat untuk bisa melakukan olahraga surfing karena tinggi gelombang di pantai ini hanya 0.9 $\mathrm{m}$ dan periode gelombang 7 detik.

4) Berdasarkan hasil perhitungan data dapat diketahui bahwa tipologinya bura dan tipe gelombang pada Sampel IV tersebut ialah plunging yang berarti bahwa tipe gelombang ini sangat cocok untuk melakukan olagraga surfing, tinggi gelombang di pantai ini $0,7 \mathrm{~m}$ dan periode gelombang 7 detik kriteria amatir/pemula, maka pada sampel IV tidak memenuhi semua syarat untuk melakukan olahraga surfing karena tinggi gelombang di pantai ini hanya $0.7 \mathrm{~m}$ dan periode gelombang 7 detik.

5) Berdasarkan hasil perhitungan data dapat diketahui bahwa tipologinya bura dan tipe gelombang pada sampel $\mathrm{V}$ tersebut ialah plunging yang berarti bahwa tipe gelombang ini sangat cocok untuk melakukan olagraga surfing, tinggi gelombang $0,5 \mathrm{~m}$ dan periode gelombang 12 detik kriteria amatir/pemula, maka pada sampel $\mathrm{V}$ tidak memenuhi semua syarat untuk bisa melakukan olahraga surfing karena tinggi gelombang di pantai ini hanya $0.5 \mathrm{~m}$.

Berdasarkan hasil perhitungan data dapat diketahui bahwa tipologinya bura dan tipe gelombang pada sampel VI tersebut ialah surging yang berarti bahwa tipe gelombang ini tidak cocok untuk melakukan olahraga surfing, tinggi gelombang 0,5 $\mathrm{m}$ dan periode gelombang 16 detik kriteria amatir/pemula, maka pada sampel VI tidak memenuhi semua 
syarat untuk bisa melakukan olahraga surfing.

\section{PEMBAHASAN}

Sesuai dengan hasil uraian pada hasil penelitian, Tipologi yang terdapat pada pantai pulau karam kecamatan tarusan realtif sama, haya terjadi perbedaan pada sampel I yaitu di bagian muara. Nilai panjang gelombang ditentukan oleh nilai periode gelombang.

Berdasarkan teori Esry Tommy Opa, 2011 yang mengatakan bahwa perubahan geomorfologi pantai terdapat parameter yaitu yang termasuk periode gelombang dan bila dikaitkan dengan kondisi fisik yang ada di lokasi penelitian apabila semakin besar nilai periode gelombang maka nilai panjang gelombang akan semakin besar.

Pantai yang berada di daerah penetilian langsung berhadapan dengan Samudera Hindia dan selat Mentawai, meskipun memiliki beberapa gugusan pulau-pulau namun pantai yang berada pada daerah penelitian tidak terlindungi oleh gelombang atau pun pulau besar, sehingga periode gelombang sangat cepat. Pantai yang terlindungi oleh teluk dan pulau besar akan memperlambat periode gelombang karena adanya penghambat gelombang menuju pantai.

Menurut Nontji dalam Putinella, 2002, gelombang yang terhempas ke pantai akan melepaskan energi. Makin tinggi gelombang makin besar tenaganya memukul ke pantai dan berdasarkan rumus panjang gelombang, Pethichk (1984) yang menitik beratkan pada panjang gelombang pantai berkaitan dengan periode gelombang.

Berdasarkan

Panjang

gelombang yang terdapat pada daerah penelitian relatif sama, hanya pada titik sampel VI nilai periode gelombang terlama yaitu dengan periode 16 detik, dan yang tercepat pada sampel IV dan V 7 detik. Nilai rata-rata periode golombang pada daerah penelitian yaitu 22,1 detik.

\section{PENUTUP}

\section{Kesimpulan}

Berdasarkan hasil penelitian yang didapat di pantai Pulau Karam Kecamatan Koto XI Tarusan Kabupaten Pesisir Selatan maka dapat diambil kesimpulan sebagai berikut:

1) Tipologi pantai dan tipe-tipe gelombang yang terdapat di sepanjang pantai Pulau Karam Kecamatan Koto XI Tarusan Kabupaten Pesisir ialah Bura (Pesisir endapan sungai).

2) Karakteristik gelombang pada Pulau Karam Kecamatan Koto XI Tarusan Kabupaten Pesisir Selatan adalah panjang gelombang tertinggi terdapat pada sampel VI yaitu 399,36 dan yang terendah terdapat pada sampel III dan IV yaitu 76,44. Indeks hempasan gelombang yang tertinggi terdapat pada sampel VI yaitu 4,5 dan yang terendah terdapat pada sampel III 0,1 .

3) Tipe gelombang yang terdapat di sepanjang pantai Pulau Karam Kecamatan Koto XI Tarusan Kabupaten Pesisir ialah plunging, splilling, surging. Sampel yang cocok untuk olahraga surfing terdapat pada sampel I ialah plunging karena memenuhi semua syarat. 


\section{DAFTAR PUSTAKA}

Pethick, John, 1984, An Introduction to Coastal Geomorphology, Maryland (USA) Edward Arnold.

Suprajaka. Dkk. 2005. Konsep dan Model Penyusunan Tipologi Pesisir Indonesia Menggunakan Teknologi Sistem Informasi Geografi. Malaysian Journal of Society and space.ISSN 2180-2491

Sutikno, 1993. Karateristik Bentuk Dan Geologi Pantai Di Indonesia. Yogjakarta : PU Wil III Direktorat Jendral Pengairan Departement Pekerjaan umum (Diklat). 